\title{
EXPERIMENTAL RESEARCH ON THE MANUFACTUREOF PARTS COMPOSING A TECHNICAL SYSTEM USING POLYMER COMPOSITE MATERIALS
}

\author{
Stelian POPESCU *, Viorel DASCĂLU **, Ioan VIRCA * \\ *,Nicolae Bălcescu”Land Forces Academy, Sibiu, Romania \\ **Ministry of Defense, Bucharest, Romania
}

fam_popesc@yahoo.com, vioreldascalu64@yahoo.com, virca_ioan@yahoo.com

\begin{abstract}
The article presents experimental research conducted by the authors for use of polymer composite materials to manufacture pressure parts of subassemblies composition of technical systems, currently manufactured from nonferrous materials. The research aimed to identify and establish a manufacturing technology specific for polymer composite materials and conducting testing and verification of resistance of manufactured parts, including their real operation conditions under pressure. The final part of the article highlights the authors' conclusions, insisting on the advantages and disadvantages of the proposed method.
\end{abstract}

Keywords: polymer materials, FIBROPLAST BURNAS STI-20material, mechanical properties.

1. Properties of composite polymer materials used in machine building

Due to the physical characteristics and very good mechanical properties of polymer composite materials, in the last decades in the field of machine building, a variety of parts and subassemblies made of these unconventional materials have been designed, tested and used, which tend to replace classical materials such as brass, bronzes and even steel.

Composite materials generally comprise a core component called a matrix in which a complementary material is dispersed in the form of fibers or particles.

The structural arrangement of the fibers within the matrix in different directions can give the resulting material favorable resistances on preferential directions [1].

The main properties of composite materials that allow their use in machine building are:
- resistance to tearing and high friction resistance, comparable to metal;

- small specific mass (density - for homogeneous bodies);

- high resistance to high temperatures;

- acceptable surface hardness;

- increased dimensional stability at temperature variations;

- increased vibration damping capacity, etc.

The most used composite materials are:

- metal matrix composites;

- composites with ceramic matrix;

- polymeric composites.

Part of the polymeric matrix composite materials used in the manufacture of parts requiring higher indexes in the field of machine building are [2]:

- MSL Thermo-Reactive composite materials (Bakelite on raw cotton textile backing, unbleached and unpainted); 
- FAGOFEN-T2

Thermo-Reactive

composite materials (Bakelite on textile backing-chopped cord thread);

- FAGOFEN-G Thermo-Reactive composite materials (Bakelite on textile backing-graphite chopped cord thread);

- SP-20V Thermo-Reactive composite materials (with chopped glass fibers);

- FIBROPLAST BURNAS STI-20 Thermo-

Reactive composite materials (with long glass-textile fibers).

FIBROPLAST BURNAS STI-20is obtained from Resol-type phenolformaldehyde resin and B 120S-arylate B as a binder, having high quality fiber glass fiber filling materials.

The product is intended for the manufacture of parts which require superior operating indexes, such as good mechanical and dielectric resistance, high thermal resistance, stability to oils, petrol and acids. The processing of this product is identical to the SP-20V polymer composite material processing.

Table 1 presents the physical and mechanical properties of the FIBROPLAST BURNAS STI-20 material in pressed state.

Table 1. Properties of the FIBROPLAST BURNAS STI-20

\begin{tabular}{|c|c|c|c|c|}
\hline $\begin{array}{l}\text { Crt. } \\
\text { no. }\end{array}$ & Characteristics & U.M. & $\begin{array}{l}\text { Conditions of } \\
\text { admissibility }\end{array}$ & Analysis method \\
\hline 1. & $\begin{array}{l}\text { Aspect of the } \\
\text { specimen's surface }\end{array}$ & - & $\begin{array}{l}\text { Smooth, glossy, } \\
\text { without bumps } \\
\text { or cracks. }\end{array}$ & $\begin{array}{l}\text { Visual } \\
\text { Disc - shaped specimen with } \\
\phi=100 \mathrm{~mm} \text { and thickness of } 2 \\
\mathrm{~mm} .\end{array}$ \\
\hline 2. & Density & $\mathrm{g} / \mathrm{cm}^{3}$ & $1,7-1,9$ & Decision 33-2004 \\
\hline 3. & $\begin{array}{ll}\text { Resistance } & \text { to } \\
\text { bending, }\left[\sigma_{\hat{i}}\right] & \\
\end{array}$ & $\mathrm{MPa}$ & $\min .140$ & SR ISO 178-1998 \\
\hline 4. & $\begin{array}{l}\text { Resistance } \\
\text { compression, }\left[\sigma_{c a}\right]\end{array}$ & $\mathrm{MPa}$ & $\min .150$ & SR ISO 178-1998 \\
\hline 5. & Tensile strength, $\left[\sigma_{a}\right]$ & $\mathrm{MPa}$ & $\min .145$ & SR ISO 178-1998 \\
\hline 5. & Resistance to shock & $\mathrm{Kj} / \mathrm{m}^{2}$ & $\min .50$ & Decision 33-2004 \\
\hline 6. & $\begin{array}{ll}\text { Martens } & \text { Thermal } \\
\text { Stability } & \\
\end{array}$ & ${ }^{0} \mathrm{C}$ & $\min .280$ & According to STAS $6174-73$ \\
\hline 7. & $\begin{array}{l}\text { Pressure contraction } \\
{[\mu]}\end{array}$ & $\%$ & $\max .0,15$ & According to SR ISO 2577-94 \\
\hline 8. & $\begin{array}{l}\text { Resistance to oil } \\
\text { action and petrol } \\
\text { action after } 24 \\
\text { hours. }\end{array}$ & $\%$ & $\pm 0,05$ & $\begin{array}{l}\text { According to: SR EN ISO 175- } \\
2002 \\
\text { and STAS } 45-86\end{array}$ \\
\hline 9. & Resistance to acids & $\%$ & $\max .0,1$ & $\begin{array}{l}\text { According to SR EN ISO } 175 \text { - } \\
2002 \text { SR EN ISO } 175-2002\end{array}$ \\
\hline
\end{tabular}

The experimental results obtained by the authors in the manufacture of FIBROPLAST BURNAS STI-20 of the pistons in the composition of a hydropneumatic system, as well as the results of their tests on their resistance to physical, chemical and mechanical stresses, under actual conditions of operation, will be presented.
FIBROPLAST BURNAS STI-20 has been chosen for experiments due to its very good physical, mechanical and technological properties.

\section{Description of the experiment}

Parts and subassemblies of technical systems are generally manufactured in a very large proportion (over $80 \%$ ) of metallic, ferrous and non-ferrous materials. 
This gives them a high degree of resistance to the physical and mechanical stresses they are subjected to [3].

The emergence of unconventional materials (ceramic materials, sintered materials, polymer composite materials, etc.) and their processing technologies had an important impact both on the principles of design and on the materials used in the construction of technical systems.

The experiments aimed at manufacturing the pistons from the composition of a hydro-pneumatic system made of FIBROPLAST BURNAS STI-20 material and their testing in the laboratory, on the test benches, to verify that they are resistant to exploitation-like stresses.

For experimentation, only two of the pistons of the hydro-pneumatic system, respectively the main piston and the plunger were selected. Obtaining these pistons from the STI-20 material required the manufacture of a hot pressing die (fig. 1).

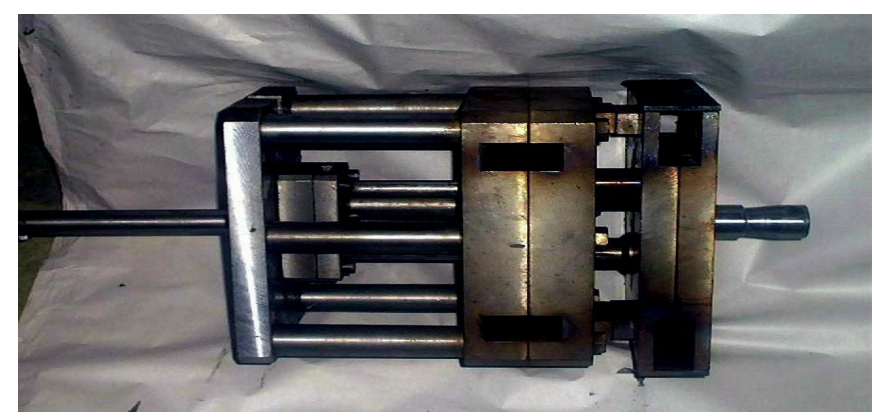

Fig. 1. Pistons' hot pressing die using STI-20 composite material

To achieve good homogeneity of the resulting parts, it is necessary to pre-store the material in the mold at $150{ }^{\circ} \mathrm{C}$ for about 10 minutes. The pre-cast material was molded and hot-pressed to obtain the final parts.

The temperatures at which the mold was heated, the dwell time, and the amount of material used for each type of piston are shown in Table 2.

The quantities of material used to obtain the main piston (1) and plunger (2) are denoted by $\mathrm{m}_{1}$ and $\mathrm{m}_{2}$ and with $\mathrm{P}_{11}$ and $\mathrm{P}_{21}$ the piston 1 obtained at sample 1 and the piston2 obtained at sample 1 .

\begin{tabular}{|c|c|c|c|c|c|c|}
\hline $\begin{array}{c}\text { No. of } \\
\text { sample }\end{array}$ & $\begin{array}{l}\text { Temp. } \\
\text { of the die } \\
{\left[{ }^{0} C\right]}\end{array}$ & $\begin{array}{l}\mathbf{m}_{1} \\
{[\mathrm{~g}]}\end{array}$ & $\begin{array}{l}\mathbf{m}_{2} \\
{[\mathrm{~g}]}\end{array}$ & \multicolumn{2}{|c|}{$\begin{array}{l}\text { Dwell time in the die } \\
{[\text { min.] }}\end{array}$} & $\begin{array}{c}\text { Obtained } \\
\text { pistons }\end{array}$ \\
\hline 1. & 220 & 52 & 90 & 25 & 25 & $\mathrm{P}_{11} ; \mathrm{P}_{21}$ \\
\hline 2. & 280 & 55 & 100 & 30 & 30 & $\mathrm{P}_{12} ; \mathrm{P}_{22}$ \\
\hline 3. & 280 & 65 & 125 & 30 & 70 & $\mathrm{P}_{13} ; \mathrm{P}_{23}$ \\
\hline 4. & 280 & 65 & 170 & 40 & 75 & $\mathrm{P}_{14} ; \mathrm{P}_{24}$ \\
\hline 5. & 280 & 65 & 170 & 40 & 75 & $\mathrm{P}_{15} ; \mathrm{P}_{25}$ \\
\hline 6. & 280 & 65 & 170 & 40 & 75 & $\mathrm{P}_{16} ; \mathrm{P}_{26}$ \\
\hline 7. & 280 & 65 & 170 & 40 & 75 & $\mathrm{P}_{17} ; \mathrm{P}_{27}$ \\
\hline
\end{tabular}

After several tests, the pistons obtained at samples 4, 5, 6 and 7 corresponded to the highest degree of homogeneity and external appearance.

The optimal pressing conditions are:

- die temperature $280^{\circ} \mathrm{C}$;
- the amount of material needed to obtain the pistons of the hydro-pneumatic system: $\mathrm{m}_{1}=65 \mathrm{~g}$ and $\mathrm{m}_{2}=170 \mathrm{~g}$;

- the dwell time in the die for the piston no. 1 is 40 minutes and for piston $2-75$ minutes. 
After removal from the die and cooling, the pistons were subjected to mechanical machining on the lathe to obtain the final shape (fig. 2).

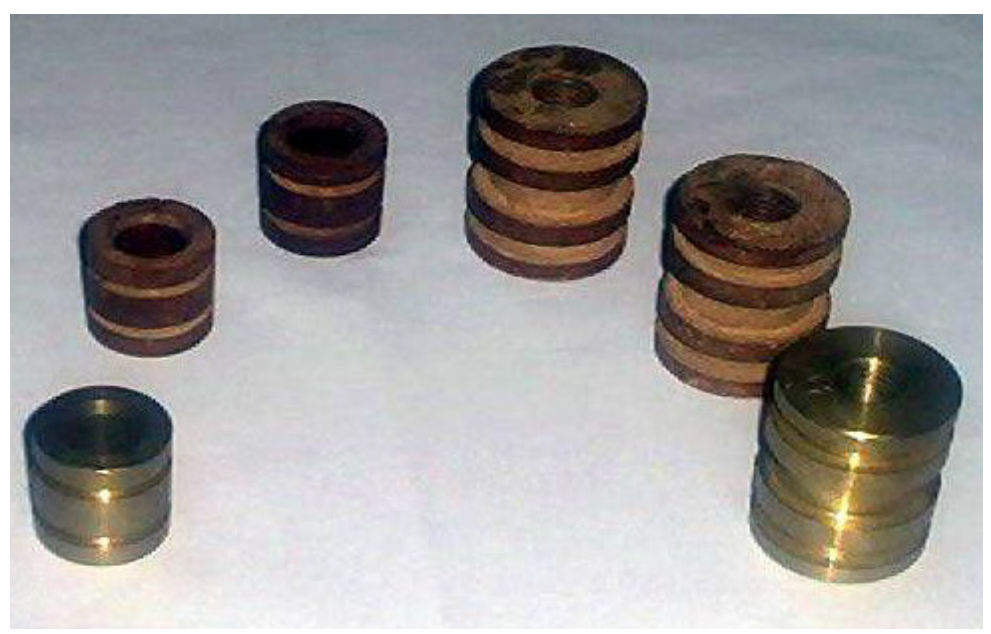

Fig. 2. Pistons of the hydro-pneumatic system made of STI-20 material and the original ones made of bronze

\section{Lab tests for the pistons}

Due to the specific requirements to which the pistons are actually subjected, the tests they will be subjected to in the laboratory can be divided into three categories:

I. Tests for the behavior of hightemperature STI-20 material;

II. STI-20 compatibility tests with STEOL-M working fluid;

III. Samples of resistance to high pressures. I. High-Temperature STI-20 Material Verification Tests

To test the behavior of high-temperature STI-20 material, two pistons, one made of bronze and the other of STI-20 composite material, were introduced for 15 minutes in a heated oven at $90^{\circ} \mathrm{C}$.After 15 minutes, their outer diameter was removed and measured.

It has been found that the diameter of the bronze piston is greater by $0.05 \mathrm{~mm}$ and the piston made of STI-20 is $0.02 \mathrm{~mm}$ larger.
No evidence of burns or deformation of the piston made of composite material has been observed.

The results obtained allow the following observations to be made:

- pistons made of STI-20 material will not grab in the hydro-pneumatic system's cylinders due to thermal expansion because the test temperature of $90^{\circ} \mathrm{C}$ was $40-50 \%$ higher than the achievable temperatures achieved inside the system under extreme operating conditions;

- the composite material STI-20 is thermally stable at $90^{\circ} \mathrm{C}$ and its thermal expansion coefficient, lower than that of the bronze, would allow the reduction of the fit between the piston and the cylinder of the hydro-pneumatic system.

II. STI-20 Compatibility Tests with STEOL$M$ Liquid

Table 3 shows the way the samples are executed and the results obtained.(fig. 2). 
Table 3

\begin{tabular}{|c|c|c|c|c|}
\hline $\begin{array}{l}\text { Nr. } \\
\text { pr. }\end{array}$ & $\begin{array}{l}\text { Piston } \\
\text { subject } \\
\text { to the } \\
\text { test }\end{array}$ & Name of the sample & Mode of execution & Obtained results \\
\hline 1. & $\begin{array}{l}\mathrm{P}_{14} \\
\mathrm{P}_{24}\end{array}$ & $\begin{array}{l}\text { Checking the behavior } \\
\text { of the pistons in the } \\
\text { working fluid at } \\
\text { ambient temperature } \\
\text { for a long time. }\end{array}$ & $\begin{array}{l}\text { The two pistons are sunk in } \\
\text { a STEOL-M vessel for } 48 \\
\text { hours at }+20^{\circ} \mathrm{C} \text {. }\end{array}$ & $\begin{array}{l}\text { There were no traces of } \\
\text { chemical reactions, } \\
\text { dimensional changes or } \\
\text { changes in surface } \\
\text { conditions. }\end{array}$ \\
\hline 2. & $\begin{array}{l}\mathrm{P}_{15} \\
\mathrm{P}_{25}\end{array}$ & $\begin{array}{l}\text { Checking the piston } \\
\text { behavior in the } \\
\text { working fluid at }+50^{\circ} \\
\text { C. }\end{array}$ & $\begin{array}{l}\text { The two pistons are sunk } \\
\text { into a STEOL-M vessel } \\
\text { heated at }+50^{\circ} \mathrm{C} \text {, and it is } \\
\text { placed in a heated oven at }+ \\
60^{\circ} \mathrm{C}, \mathrm{t}=30 \mathrm{~min}\end{array}$ & $\begin{array}{l}\text { No traces of chemical } \\
\text { reactions or cracks on } \\
\text { the pistons' surfaces } \\
\text { have been observed. }\end{array}$ \\
\hline 3. & $\begin{array}{l}\mathrm{P}_{16} \\
\mathrm{P}_{26}\end{array}$ & $\begin{array}{l}\text { Checking the piston } \\
\text { behavior in the } \\
\text { working fluid at }-25^{\circ} \mathrm{C} \text {. }\end{array}$ & $\begin{array}{l}\text { The two pistons are sunk } \\
\text { into a STEOL-M pot and } \\
\text { placed in a freezer } t=60 \\
\text { min }\end{array}$ & $\begin{array}{l}\text { No traces of chemical } \\
\text { reactions or cracks on } \\
\text { the pistons surfaces } \\
\text { have been observed. }\end{array}$ \\
\hline
\end{tabular}

Following the evidence, the following conclusions were drawn:

- STI-20 material is chemically inert to the STEOL-M liquid;

- After immersing in the working fluid, heating to $+50^{\circ} \mathrm{C}$, cooling to $-25^{\circ} \mathrm{C}$ and returning to ambient temperature, the initial Brinell hardness of the material $(65 \mathrm{HB})$ was preserved;

- Pistons do not visibly change their size or shape to $+50^{\circ} \mathrm{C}$ or cooled down to $-25^{\circ} \mathrm{C}$. III. Samples of resistance to high pressures The high pressure piston resistance tests shall be carried out by inserting them into a piston cylinder (figure 3), connected to a manually operated hydraulic pump.

Generally, in hydro-pneumatic systems of these types of pistons, the initial working pressure is 5.5-6.5 [MPa] and during operation it reaches values of 14-16 [MPa].

The pressure resistance samples are intended to determine whether the pistons bear this pressure without being destroyed. Pistons will be inserted into the hydraulic cylinder in three distinct situations:

a. alone;

b. with a corresponding diameter mandrel, inserted inside the pistons;

c. the pistons are inserted into a cylinder having an internal diameter approximately equal to the outer diameter of the pistons, having previously been inserted into the pistons' holes with a corresponding diameter mandrel (fig 3).

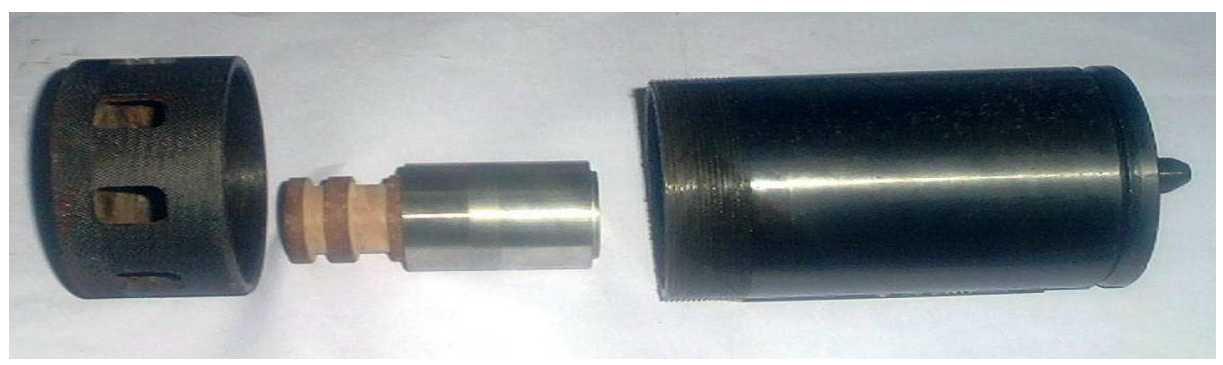

Fig. 3. Cylinder for pistons' pressure hydraulic tests 
The way the samples are executed and the results obtained are presented in table 4 . A pressure gauge for liquids, 0-25 [MPa], class 0.6 , was used to measure the pressure, mounted by a reduction on the hydraulic pump.

\begin{tabular}{|l|l|l|}
\hline $\begin{array}{l}\text { No. of } \\
\text { piston }\end{array}$ & \multicolumn{1}{|c|}{ Sample's mode of operation } & \multicolumn{1}{c|}{ Results obtained } \\
\hline $\mathrm{P}_{14}$ & $\begin{array}{l}\text { The pressure increased rapidly to } 10 \mathrm{MPa} \text {, it } \\
\text { was held for } 5 \text { minutes, then the pressure } \\
\text { was slowly increased to } 13 \mathrm{MPa} \text { in the } \\
\text { situation a. (Simple piston) }\end{array}$ & $\begin{array}{l}\text { The piston cracked at a pressure of } \\
13 \mathrm{MPa} .\end{array}$ \\
\hline $\mathrm{P}_{15}$ & $\begin{array}{l}\text { The pressure increased slowly to } 16 \mathrm{MPa} \text { in } \\
\text { situation b. (with a mandrel inserted inside) }\end{array}$ & $\begin{array}{l}\text { At a pressure of 16 MPa, the } \\
\text { piston cracked. }\end{array}$ \\
\hline $\mathrm{P}_{16}$ & $\begin{array}{l}\text { The pressure increased rapidly, it was } \\
\text { maintained at } 15 \mathrm{MPa} \text { for } 10 \text { minutes, then } \\
\text { the pressure increased rapidly in situationc. } \\
\text { (with a mandrel inside, inserted into a } \\
\text { cylinder and pressed by a piston). }\end{array}$ & $\begin{array}{l}\text { The piston cracked at a pressure of } \\
16.2 \mathrm{MPa} .\end{array}$ \\
\hline $\mathrm{P}_{17}$ & $\begin{array}{l}\text { The pressure grew slowly, the piston in } \\
\text { situation c.(with a mandrel inside, inserted } \\
\text { in a cylinder and pressed by a piston). }\end{array}$ & $\begin{array}{l}\text { The piston cracks at a pressure of } \\
18 \mathrm{MPa} .\end{array}$ \\
\hline $\mathrm{P}_{24}$ & $\begin{array}{l}\text { Pressure increased rapidly to } 10 \mathrm{MPa} \text {, it was } \\
\text { maintained for } 5 \text { minutes, then the pressure } \\
\text { was slowly increased to } 14 \mathrm{MPa} \text { in situation } \\
\text { a. (Single piston). }\end{array}$ & $\begin{array}{l}\text { The piston cracked at a pressure of } \\
14 \mathrm{MPa} .\end{array}$ \\
\hline $\mathrm{P}_{25}$ & $\begin{array}{l}\text { The pressure increased slowly to } 17 \mathrm{MPa} \text { in } \\
\text { situation b. (with a mandrel inserted inside) }\end{array}$ & $\begin{array}{l}\text { At a pressure of 17 MPa, the } \\
\text { piston has cracked but did not } \\
\text { completely deteriorate. }\end{array}$ \\
\hline $\mathrm{P}_{26}$ & $\begin{array}{l}\text { The pressure grew slowly, the piston in } \\
\text { situation c. (with an internal mandrel, } \\
\text { inserted in a cylinder and pressed by a } \\
\text { piston). } \\
\text { maintained at } 18 \text { MPa pressure for } 10 \\
\text { minutes. Then the pressure raised rapidly, } \\
\text { the piston in situation c. } \\
\text { cracked but did not completely } \\
\text { deteriorate. }\end{array}$ & $\begin{array}{l}\text { The piston cracked at a pressure of } \\
19 \mathrm{MPa} .\end{array}$ \\
\hline
\end{tabular}

The modes of behavior of the pistons graphically in Figure 4, for the piston no. throughout the samples are shown $\quad 1$, and in Figure 5, for piston no. 2.

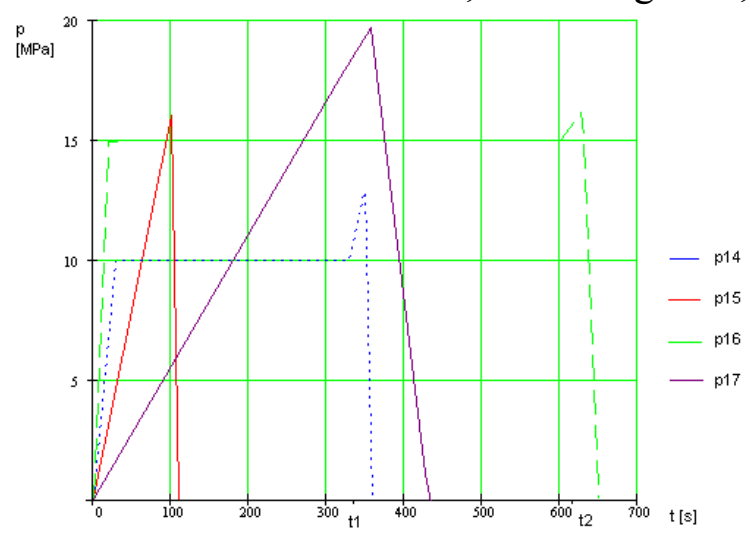

Fig. 4. Pressure tests' graph of piston no. 1 


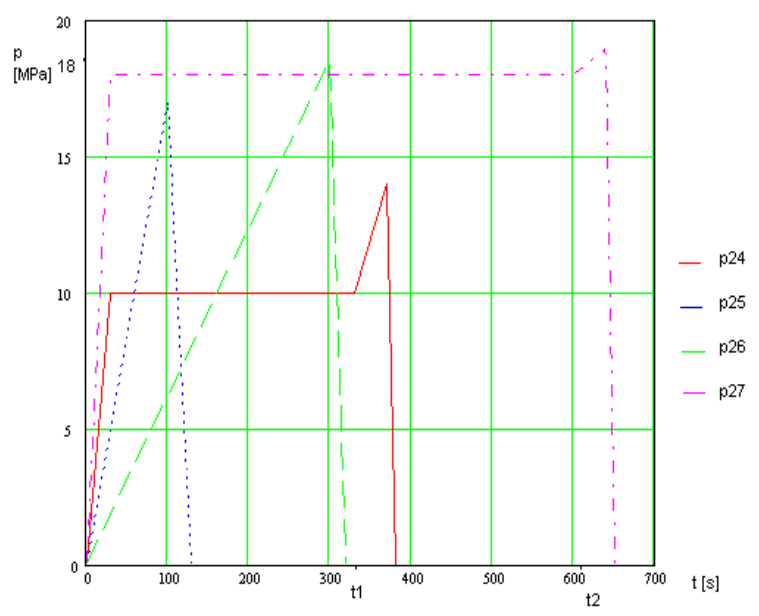

Fig. 5. Pressure tests' graph of piston no. 2

From the analysis of the graphs (Figure 4 and Figure 5) it is observed that:

- Piston no. 1 resists, in the mounted state (inserted into the cylinder and with a mandrel inside) at a pressure of about 15 MPa for at least 10 minutes;

- Piston no. 2 resists, in the mounted state, at a pressure of about $18 \mathrm{MPa}$ for at least 10 minutes.
The time the pressure in the hydropneumatic system reaches the maximum value during operation is approximately 0.2-0.4 seconds. In other words, during the operation of 1000 cycles, the hydropneumatic system is subjected to maximum pressure for about 3-7 minutes.

Pistons' damage is shown in Figure 6.

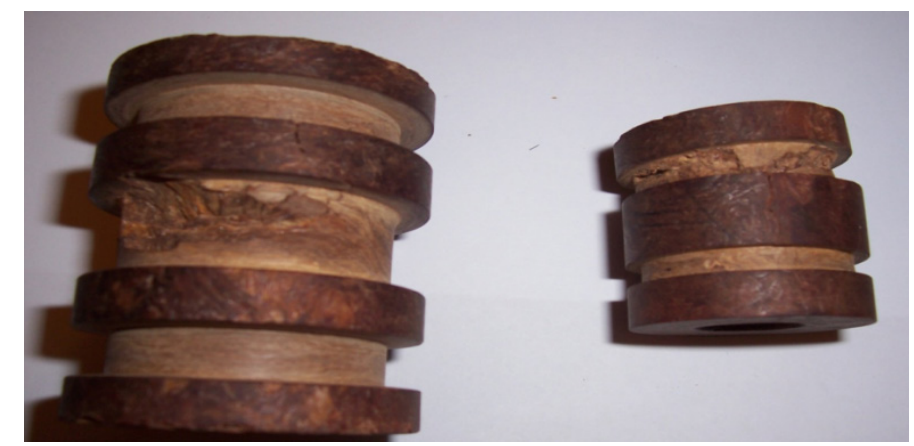

Fig. 6. Recovery pistons made of FIBROPLAST BURNAS STI-20- damaged

The structures of the two pistons before and after completion of the tests are shown in

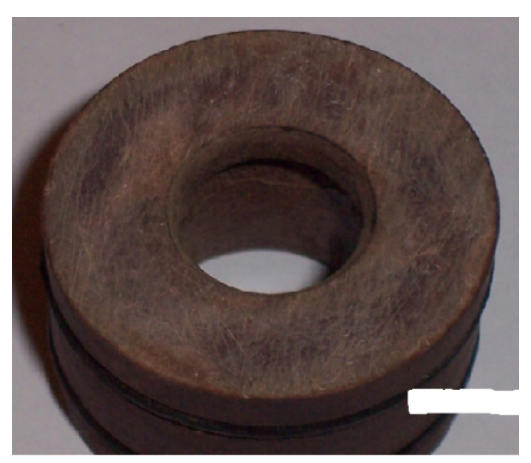

Fig. 7. Structure of piston no. 1 and 2before the beginning of the tests

Fig. 7, Fig. 8 and Fig. 9.

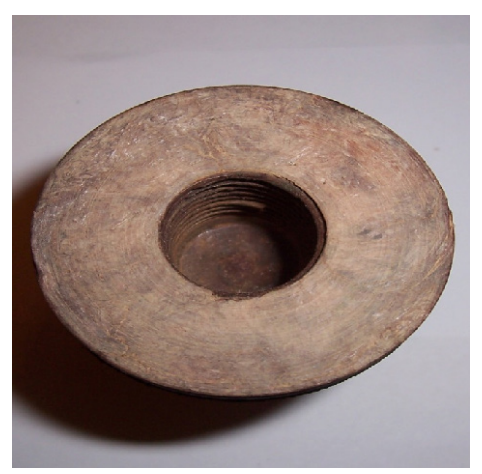


From the analysis of Figure 7 it can be seen that the structures of the two pistons, prior to the beginning of the high pressure resistance tests, were homogeneous and amorphous.

After the destruction of the pistons (Figure 8 and 9), it is observed that:

- the piston structures remain amorphous;
- cracks in piston bodies occur in random directions;

- cracks occur in areas where tension concentrators are present;

- for both pistons, these areas are located at the bottom edges of the channels turned on the outer surfaces;

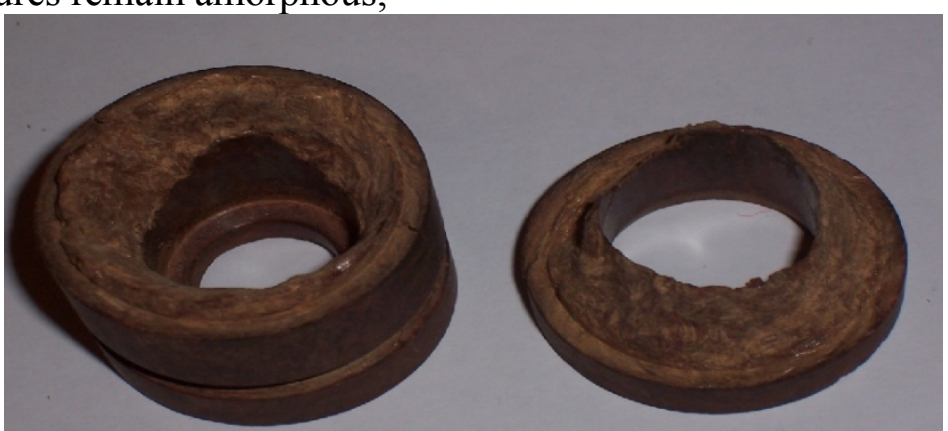

Fig. 8. Structure of the piston no. 1, damaged, after completion of the tests

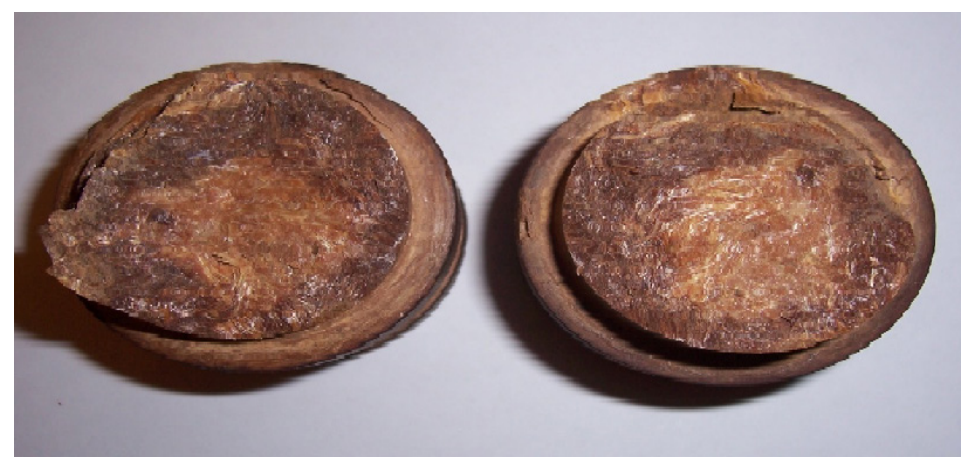

Fig. 9. Structure of the piston no. 2, damaged, after completion of the tests

In order to reduce the negative effects of stress concentrators on piston resistance, it is necessary to make the external channels turning with a profiled cutter that achieves a radius of $0.5 \mathrm{~mm}$ of the bottom of the channel (STAS 7320 / 3-1983).

Because the STI-20 composite pistons, during the tests, have lasted for at least 10 minutes at pressures of 15 or $18 \mathrm{MPa}$, it can be appreciated that they resist in terms of reliability of the stresses to which the hydro-pneumatic system is subjected between two average repairs, up to 4 years. As a result, it can be concluded that the use of polymeric composite materials in the manufacture of pistons in the composition of high-pressure hydro-pneumatic systems is possible and beneficial by the advantages of this technological solution.

[1] Amza Gheorghe, Tratat de tehnologia materialelor. Editura Academiei Române, Bucureşti, 2002.

[2] Iacobescu, A. - Cercetări privind realizarea ajutajelor motoarelor rachetă ale muniţiei reactive din materiale neconvenţionale. Referat III doctorat, Universitatea "Lucian Blaga", Sibiu, 1999.

[3] Dascălu Viorel, Popescu Stelian, Tendinţe şi realizări constructive în dezvoltarea gurilor de foc de artilerie moderne. Proceedings of $09^{\text {th }}$ International Scientific Conference KBO, Sibiu, Romania, November, 2002. 